\title{
Balancing Conflicting Supply Chain Stakeholder Interests: The Big Procurement Practioner's Dilemma
}

\author{
Jackson Ndolo \\ School of Business and Economics \\ Mount Kenya University \\ Corresponding author \\ Eunice Njagi \\ School of Business and Economics \\ South Eastern Kenya University
}

\begin{abstract}
Effective Supply chain management practices dictate fair and balanced treatment of all critical players in any organization's supply chain for better performance. Each of the players has their interests though occasionally some are shared; this scenario puts the position of the procurement professionals at cross roads with buyers and suppliers as they implement their employers' objectives within a regulated environment. The paper explores the dilemma created by variant stakeholder interests in the procurement system and proposes a consultative and trade off approach for procurement professional so as to achieve desired goals. The researchers surveyed all 74 procurement professional who attended the first KISM procurement research forum held at New Stanley hotel in Nairobi in June 2014, opinions were sorted using semi structured questionnaires and analyzed using SPSS. The study focused mostly on public sector procurement practioners since the stakeholders are similar as stipulated by the existing legal framework, private regulations mostly vary from organization to another depending on governance and positioning of procurement. Majority of the procurement professionals cited balancing of variant stakeholder interests as their biggest challenge.
\end{abstract}

Key Words: Dilemma, collaboration, sustainability, Procurement Practioner.

\section{INTRODUCTION}

In many developing economies procurement profession is treated as a "back -office" function, not much has been done to explore and address challenges facing the Procurement professionals (Takuta, M. \& Saruchera, 2015). The researchers in their study titled "challenges facing procurement professionals in developing economies: unlocking value through professional international purchasing"; limited recognition, increasing unethical behavior, poor supplier delivery, poor regulatory environment, varying supplier standards and poor corporate governance were identified as the main challenges faced by procurement profession in developing countries. Procurement has become an integral part of organizational performance and it is drawing increased attention from top to lower management levels. Despite shrinking budgets, procurement professionals are responsible for spending a huge proportion of companies' revenues of national budget (Anton, Bogetoft \& Thorsen 2007; Levaggi 1999). The term Stakeholder has become increasingly important as an integral part of the procurement process. Effective Supply chain management practices dictate fair and 
balanced treatment of all critical players in any organization's supply chain for better performance.

The key drivers of supply chain performance are infrastructure, technology, information and people. The people aspect comprises of buyers, suppliers and the organization's people (business owners and managers). The people are the most critical for they allocate and manage all the other drivers. Each of the players has their interests though occasionally some are shared, this is scenario puts the position of the procurement professionals at cross road with buyers and suppliers as they implement their employers objectives. Internally users view procurement professionals as procedural officers who rely on static laws to deny them timely necessary requirements. Sometimes the pressures may be too much to bear. The current public procurement sector in Kenya is riddled with all manner of accusations amongst stakeholders in the system. With all this the procurement practioner is at the center stage. The pressure is too much sometimes depicting a worn out procurement practioner who is stuck between two hard rocks (citizenry and the political machinery). The varying and conflicting stakeholders' interests are a real nightmare to balance notwithstanding the static legal framework. This poses the big question, how does the procurement professional mitigate through the dirty waters without being drowned?. It's against this background the researchers sought to identify the major conflicting supply chain stakeholder interests and the resulting dilemma.

\section{OBJECTIVES OF THE STUDY}

The paper sought to bring forth the role of procurement professionals in harmonizing stakeholder interests and proposes the safest strategy for procurement professionals to achieve harmony and support from the stakeholders in their supply chains.

\section{STAKEHOLDER THEORY}

Stakeholder theory suggests that the purpose of a business is to create as much value as possible for stakeholders. In order to succeed and be sustainable over time, executives must keep the interests of customers, suppliers, employees, communities and shareholders aligned and going in the same direction. Innovation to keep these interests aligned is more important than the easy strategy of trading off the interests of stakeholders against each other. Hence, by managing for stakeholders, executives will also create as much value as possible for shareholders and other financiers. (Financial times, 2014). In general, stakeholders are groups of people whose interests are considered to be most important for the overall success of a project. They have the capability to influence the project and receive both gain or lose from the success or failure of a system. According to Romenti (2010), stakeholders are considered social subjects who influence each other's perceptions, rather than isolated individuals who process information. Successful completion of projects is therefore dependent on meeting the expectation of stakeholders (Freeman, 2007). Project success and failure is directly related to its stakeholders" perceptions of the value created by the project and the nature of their relationship with the project team (Bourne, 2005). The success, or failure, is strongly influenced by both the expectations and perceptions of its stakeholders, and the capability and willingness of project managers to manage these factors and the organization's politics team (Bourne, 2005).

\section{PUBLIC PROCUREMENT SYSTEM IN KENYA}

The current Public Procurement system in Kenya is heavily regulated by various acts of parliament; key to these is the public procurement and Disposal Act 2005 and its regulations. This is the law that guides and supersedes all the other laws including international agreements on matters pertaining to procurement as long as public funds are involved (GoK, 2005). Others include the anti-corruption and ethics Act, The public private partnerships Act 
2012, Chapter 6 of the constitution of Kenya etc. The legal framework has been cited as a stumbling block to government's service delivery more so on long timeframes stipulated for various procurement methods (Ndolo, 2014). According to Njagi (2014) the emergency of new procurement practices notably government to government procurement agreements and procurement proceedings being done above the board, preference and reservation clauses for the youth/women make the whole scenario more complex. Inter-professional conflicts don't ease the pressure either. This has led to controversial dismissal of senior officers, majority have pending cases in court or numberless registered complains to regulatory bodies. As most of the stakeholder's demands and interests sometimes conflict with each other, organization must set appropriate strategic goals and priorities to bring sustainability to meet these demands and interests. The ethical inclination of the procurement process should be viewed as the responsibility of all stakeholders notably; suppliers, donors, procuring entities, beneficiaries and the Kenyan citizenry. A continuously improved procurement system would be the preference of each of the stakeholders since it will help in mitigating challenges that keep on popping up. Success will be measured by the extent to which the public can see a significant increase in the quality of service delivery and achieve value for money.

\section{KEY STAKEHOLDERS IN THE KENYAN PROCUREMENT SYSTEM}

Effective stakeholder management is crucial to project's procurement success and it's really impossible to manage stakeholders if it's not known who they are and the motive of their involvement. Stakeholder can be classified according to their interest and power. Key stakeholders of the Kenyan procurement system include; The Government, legislature, regulatory bodies, procurement entities, procurement professionals, the citizenship, the courts, Activists and the media. The government sets the agenda by proposing to parliament approval of relevant legal framework geared towards a value based procurement system that is efficient and effective. These laws are usually aligned to the political agenda of the government of the day for example the drafting, passage and adoption of the preference and reservation clause in the procurement act promotes the jubilee's government goal of giving more opportunities to youth and women. The legislature debates and approves or rejects such proposal to laws. It is also mandated with the supervisory role of deciding on the effectiveness of the system. The effectiveness of such laws is subject to another discussion. Procurement professionals are the implementers of such laws. Regulatory bodies assist the procurement entities in the usage of the laws. The courts only get involved in the procurement process when claims of malpractices are reported by any of the parties to the system. The media and activists play the key role of creating awareness to the public on key laws, opportunities as well as malpractices in the public system. This has occasionally been viewed as antigovernment or existing procurement system.

\section{METHODOLOGY}

The study adopted an exploratory descriptive methodology due to the insufficiency of original research related to procurement issues in developing economies. The questionnaires were emailed to the respondents. A sequential process of combining the existing procurement literature with real-world practices was adopted. Data was collected using questionnaires and analyzed using descriptive statistics as shown in table 1 below.

\section{Response Rate}

\section{RESULTS AND DISCUSSIONS}

After sending out 74 questionnaires, 69 were properly filled and returned which represents a $93 \%$ response rate which is adequate. 
Table 1 below shows the descriptive statistics of the questionnaire results

Table 1: Descriptive Statistics

\begin{tabular}{|l|r|r|r|r|r|}
\hline & $\mathrm{N}$ & Min & Max & Mean & $\begin{array}{c}\text { Std. } \\
\text { Deviation }\end{array}$ \\
\hline $\begin{array}{l}\text { Balancing varying stakeholder's interest } \\
\text { is my biggest challenge in procurement }\end{array}$ & 69 & 1.00 & 4.00 & 1.2754 & .70469 \\
$\begin{array}{l}\text { My qualification help to meet } \\
\text { stakeholder' interest }\end{array}$ & 69 & 1.00 & 4.00 & 3.6667 & .76055 \\
$\begin{array}{l}\text { Government regulation helps me to meet } \\
\text { stakeholder's interest }\end{array}$ & 69 & 1.00 & 4.00 & 2.3043 & 1.37525 \\
$\begin{array}{l}\text { Stakeholder's consultation helped me to } \\
\text { meet stakeholder's interest }\end{array}$ & 69 & 1.00 & 4.00 & 2.9275 & 1.56542 \\
$\begin{array}{l}\text { Trade-off is key in meeting stakeholder } \\
\text { interest in procurement }\end{array}$ & 69 & 1.00 & 5.00 & 3.5072 & 1.45140 \\
\hline
\end{tabular}

Procurement professional's qualification and trade-off as means of achieving stakeholder interests had the highest means. This gives the variant views of the procurement professionals. The professionals' views on stakeholder consultation and trade-off had the highest standard deviation an indication of a wide range of the views from the procurement professionals. Balancing varying stakeholder interests received a mean of 1.2754 and standard deviation of 0.70469 the lowest and the least varying.

\section{CONCLUSION}

Based on the findings of the study, the following conclusion is drawn. The study reveals that procurement professional qualification, Trade-off and Stakeholder's consultation helped the procurement professionals meet stakeholder's interests. This is justifiable due to the extended democratic space, adoption of new project management practice that promotes stakeholder involvement. Many professionals are also back in class to improve on their skills hence the high rating of professionalism qualifications. Stakeholder consultation is also rated highly which is in line with stakeholder theory that while balancing stakeholder interests and government regulations assisted to a lower extend in meeting stakeholder interests. This can be attributed to the accusations that government regulations are an obstruction to efficient and effective public procurement in Kenya. This justifies the myriad court cases pertaining to flouting of procurement procedures for the officers don't seem to think government regulations help them in meeting stakeholder interests hence there is little chance of application.

\section{RECOMMENDATIONS}

Based on the findings of this study, the following recommendations are made;

1. A consultative approach both by procurement practioners and policy makers should be adopted so as to win key stakeholder support in the procurement process.

2. Familiarization of public legal framework among stakeholders so as to mitigate some of the unnecessary stakeholder conflicts 


\section{References}

1. Heiko Spitzeck, Erik G. Hansen, (2010),"Stakeholder governance: how stakeholders influence corporate decision making", Corporate Governance: The international journal of business in society.

2. Ndolo J. \& Njagi E., (2014). “Are Kenyans Suffering from Procurement Nightmare Culture?”, International Journal of Supply of Management.

3. Nigel M. de Bussy, Lorissa Kelly, (2010),"Stakeholders, politics and power: Towards an understanding of stakeholder identification and salience in government", Journal of Communication Management.

4. Silvia Ayuso, Miguel Ángel Rodríguez, Roberto García-Castro, Miguel Ángel Ariño, (2011),"Does stakeholder engagement promote sustainable innovation orientation?", Industrial Management \& Data Systems.

5. Stefania Romenti, (2010) "Reputation and stakeholder engagement: an Italian case study", Journal of Communication Management.

6. Tukuta, M. \& Saruchera, F., (2015). “Challenges facing procurement professionals in developing economies: Unlocking value through professional international Purchasing”, Journal of Transport and Supply Chain management. 